\title{
Community in Julio Cortázar's Libro de Manuel
}

\author{
Grace A. Gomashie \\ Department of Modern Languages and Literatures, Western University, Ontario, Canada
}

Received: 24-09-2016

doi:10.7575/aiac.ijclts.v.4n.4p.60
Accepted: 16-10-2016

Published: 31-10-2016

URL: http://dx.doi.org/10.7575/aiac.ijclts.v.4n.4p.60

\begin{abstract}
Libro de Manuel (A Manual for Manuel), Julio Cortázar's 1973 novel, revolves around a small revolutionary group of South-American expatriates based in Paris named la Joda and its quest to raise the consciousness of the public about social injustice as well as to free some political prisoners. This article focuses on various theoretical concepts of community, and how these relate to the fictional community of la Joda. La Joda is a diverse community made up of members who all contribute their part in mini-revolutions and it represents for its members a quest for freedom at an individual and a collective level. La Joda also has a sense of belonging, tolerance and trust among its members. Cortázar succeeds in creating a fictional intellectual and revolutionary community with some real-world characteristics, that embarks on a quixotic mission to change the world.
\end{abstract}

Keywords: Social Justice, Community, Revolution, Conciousness

\section{Introduction}

Julio Cortázar's 1973 novel, Libro de Manuel (A Manual for Manuel, 1978, the English translation), focuses on a small revolutionary group of South-American expatriates based in Paris named la Joda (the Screwery in English) and their quest to raise the consciousness of the public about social injustice as well as to free some political prisoners. Members of la Joda include Marcos the leader, Lonstein, El-que-te-dije (the-one-I-told-you), Susana, Patricio, Heredia, Gómez, Gladis, Monique, Lucien Verneuil, Andrés, Ludmilla, Fernando, Roland, Oscar, and Manuel, the infant son of Susana and Patricio (Cortázar 1978:11). Cortázar incorporates newspaper clippings in the main text to give the novel "a new sense of political immediacy... (about) Latin America during the 1970s" (Juan-Navarro 1999). While the novel has an unstructured format, Planells (1980:43) describes the four main plot lines as: 1) the making of a scrapbook as a testimonial for Manuel by collecting newspaper clippings about political repression and military rule in Latin America, acts of armed resistance against political repression, and eccentric news and advertisements, 2) the story of the main character Andrés and his affair with two women Francine and Ludmilla, 3) the activities of la Joda including their plan to kidnap a diplomat in their quest to free political prisoners, and 4) the story of Lonstein who ruptures linguistic and sexual taboos. Libro de Manuel has been criticized for the author's controversial support for armed violence against political repression and his dishonorable depiction of female characters (Yovanovich 2011; Francescato 1976). Cortázar portrays violence as a justifiable and necessary tool for a change in the status quo (Yovanovich 2011; Juan-Navarro 1999). This article examines various theoretical concepts of community, and how these relate to the fictional community of la Joda created by Julio Cortázar.

\section{Concepts of community and application to La Joda}

Delanty (2010) proposes four main approaches or positions in the study of community:

a. "Communitarian philosophy which associates community with disadvantaged urban localities and requiring government support responses and civic voluntarism such as community regeneration, community health projects, etc." (xii),

b. "Community is seen as the search for belonging and the emphasis is on the cultural construction of identity...Emphasis is on community as self versus other" (xii).

c. "Community is inspired by postmodern politics and radical democracy, looking at community in terms of political consciousness and collective action...emphasis is on the collective 'we' opposing injustice" (xii-xiii).

d. Community built around "global communications, transnational movements and the Internet, whereby community becomes cosmopolitanized and constituted in new relations of virtual proximity and distance" (xiii). In this approach to community, technology plays a major role in establishing and "reshaping social relations" (xiii).

The common attribute of all four positions is a sense of belonging. Of the four approaches, the third one most appropriately characterizes la Joda. La Joda is politically motivated, locally-based with global contacts, subversive to the established order, modern and reactionary or progressive, to use the words of Delanty (2010: xi). Although the members of la Joda sometimes have different perspectives on the revolution, what is commonly shared is the need to stop the dictatorial oppression and injustice in Latin America, making their basis for mobilizing largely political and social to a considerable extent. Their base was in Paris but they were globally organized in the sense that Marcos spent a lot of time in Andrés 's house placing many international calls. They had contacts in Brazil, London, and of course 
Argentina, as it was evidenced in the episode involving Oscar, Gladis, the turquoise penguin and the armadillos (Cortázar 1978: 93-95; 104-112). They were modern in their beliefs as they were more open to traditional concepts of taboos like sexual exoticism, as depicted by Lonstein. Finally, they subverted the established or bourgeois order in more ways than one in a reactionary way. Progression is seen in the mini-revolutions of la Joda; from shrieks in theatres by Gomez, Marcos, Susana and Patricia (57-61); Gómez's eating on his feet in the elegant Vagenade restaurant (64); the affair of transferring counterfeit dollars; and infiltrating the banks to the successful kidnapping of the VIP in exchange for a number of comrades from five or six countries.

La Joda fits Flores' description of communities as an ideology which unites members into working for the collective good. In the same vein as Etzioni (1995) and Kymlicka (1996), she points out that proponents of community "se definan por compartir una misma concepción del bien y se esfuerzan por promover una política del bien común, aun cuando ello limite la capacidad de sus miembros individuales para realizar sus fines" (Flores 2011:29-30). The members are united by a common ideology of political justice and their need to correct the injustices of society because when one looks at the makeup of La Joda, it is surprising how diverse they are. It comprises Marcos and Andrés (who joined later) as intellectuals with divergent views on the way revolution should take; Lonstein the Jewish rabbi; Panamanian Gomez who is addicted to stamp collection; multilingual Susana; Brazilian Heredia; French Lucien Verneuil, Roland and Monique who are distressed about Latin Americans' disregard for time; Polish Ludmilla with her optimism and Chilean Fernando. What else can unite these people except a common ideology? Flores' (2011) definition could be closely linked to Blackshaw's (2010) concept of community as an idea that "fired the imagination like no other idea - to pursue an ideal, to embody a dream, to struggle against loss." (137).

Furthermore, we explore the emotional or visceral part of community in la Joda along the lines of Amit's (2002) opinion that "the visceral nature of community...[is] not coldly calculated contracts, but embodied, sensual and emotionally charged affiliations" (Amit 2002:16). We realized that members are involved personally with each other and this serve as a source of motivation for them. For instance, Patricio and Susana are married with a son, Manuel, whom they hope will become a new man; Ludmilla who originally joins for fun like the character Alba in La Casa de los Espiritus (Allende 1982) and is later motivated by her love for Marcos; Monique and Gómez are a couple; and the other couple is Gladis and Oscar; even Lonstein and the-one-I-told -you share a great bond as the latter is seen as the only one who understands the former. Marcos has the respect of the others in the group who obey his directions and pledge allegiance to him as some sacrifice their lives in the end. We observe in la Joda, the three common values or qualities that appear regularly in the discourse of communal life (as stated in Smith 2001):1) tolerance which Walzer (1997: 11) translates as "an openness to others; curiosity, perhaps even respect, a willingness to listen and learn", 2) reciprocity which Putnam (2000: 134) describes as "I'll do this for you now, without expecting anything immediately in return, and perhaps without even knowing you, confident that down the road you or someone else will return the favor", and 3) trust, which (Smith 2011) defines as "the confident expectation that people, institutions and things will act in a consistent, honest and appropriate way". The first and third values are more evident in the novel as la Joda is seen as a tolerant community in which people of different nationalities, gender and sexuality are accepted without discrimination. Trustworthiness is also manifested among the group as all members are reliable and do not betray each other. The role of the leader, Marcos, shows critical judgment when he shared with Ludmilla and Andrés some information on the preparations of la Joda even when they were not part of it.

\section{Community for individual members of la Joda}

In continuation, we analyse the perception of community of some of the protagonists of la Joda in line with Turner's (1969) and Cohen's (1985) views on community as symbolic and liminal. According to Turner (1969), community should not be reduced to a fixed and spatial grouping. The symbolic nature of community shapes social relations and creates strong links between members of a social group. Cohen (1985) builds on Turner's views by proposing that community can also be both an ideal and a symbol as people participating within the same ritual will attribute different meanings to it. Consequently, we are interested in the interpretations of la Joda of some of the members; we begin with leader Marcos.

Marcos's views' fits Durkheim's (1964) perspective of community built on organic solidarity (division of labour) or moral individualism based on "cooperation, pluralism and certain individualism." (cited in Delanty 2010:28). Marcos believes in the division of labor of society and values the efforts of each member. He is in favor of a revolution that subverts the bourgeois order and thinks total revolution and change can and should be achieved on diverse levels including language and sexuality. Fernández Utrera (1996:231) notes that "Marcos comprende que las microagitaciones o el lenguaje de Lonstein son formas distintas y coordinadas de subvertir las estructuras del mundo burgués", in contrast with Andrés who does not credit them with any impact. This explains Marcos's acceptance of Lonstein into la Joda. He is not against the use of necessary violence to achieve his goals, unlike Andrés. However, he does not look to destroy the whole order as the extremists Gómez and Lucien Verneuil. Consequently, we realized that la Joda takes on a violent form as Delanty (2010) argues against theorists like Turner (1969) and Cohen (1985) for not acknowledging that communitas can take violent forms in relation to other groups. That is violence by the dominant groups can generate a reaction of violence in the subordinate groups. La Joda participated in violent acts when its members kidnapped the VIP, Don Gualberto. To show a marked difference between la Joda and the dictatorial regimes in Latin America, they did not use torture but treated the kidnapped diplomat with respect. Marcos is willing to risk his life for the collective good. Cortázar writes, there are "types like Marcos and Oscar...in la Joda because of Manuel ...they were doing it for him, for every Manuel in every corner of the world, trying to help him so that someday he 
would enter a different cycle." (Cortazar1978: 185). This is the moral individualism Durkheim (1964) prefers to the egoistic individualism Andrés portrays in the initial stages.

For Andrés, community "draws its psychological strength from levels of motivation deeper than those of mere volition and interest, and it achieves its fulfilment in the submergence of individual will that is not possible in unions of mere convenience or rational assent. Community is a fusion of feeling and thought, of tradition and commitment, of membership and volition." (Nisbet, 2004: 48). Nisbet (2004) perfectly captures Andrés 's journey towards la Joda. One might attribute Andrés 's final decision to join based on his attachment to Ludmilla and his final deciphering of the Fritz Lang dream telling him to wake up. We see Andrés on a personal and political journey to discover himself as he is caught between two women who represent two worlds, Francine and Ludmilla. In Yovanovich's (2011) words, Ludmilla represents "la fuerza positiva y creadora, la inspiración y el positivismo europeo" whereas, according to Martín (2009), Francine stands for "el pragmatismo, la vida cómoda, tipificada y familiar del futuro cierto" without surprises. Later Andrés realises that society is based on thin values as proposed by traditional theorists of community when he decides to shock Francine out of her little bourgeois and secure world by taking her to a strip club and finally to Hotel Terrass where he violates her in a room overlooking a cemetery. When Andrés finally joins la Joda, he commits to his new role as the chronicler, taking the place of the-one-I-told-you. However, Andrés does not want to renounce the pleasures of the bourgeois life; he does not want sacrifice his individualism on the altar of collectivism. He is afraid of the Gómezes and Lucien Verneuils of this world who seek to overhaul the whole system but, in the end, they replace the same dictatorial regimes they opposed.

For Lonstein, community or la Joda could be seen as a sense of belonging. Cortázar uses Lonstein to break the silence on traditional taboos of what is termed as depraved sexual behaviour and to liberate language. Lonstein is a known masturbator, necrophile, had a one-time failed homosexual experience and is unable to sustain any relation with a woman. In the terms of society, he is an outcast but in La Joda, there is a place for him where he can openly share his experiences, pains and fears no matter how painful they are. By sharing those memories and nightmares with the-one-Itold-you, he breaks the hold that these experiences have of him. The scene of Andrés and Francine in Hotel Terrass is also an attack on existing sexual taboos. As already mentioned in Lonstein's relationship with Marcos and by extension la Joda, Lonstein represents linguistic liberation and the revival of language to reflect reality.

The-one-I-told-you is first seen as objective chronicler of events in the novel but as we later observe he cannot help but judge, analyze and evaluate things in his selection of articles for the manual, meaning that community is an emotional setting which cannot be devoid of subjectivity (Amit 2002). As Turner (1969) proposes, community creates powerful links between members as in the case of the-one-I-told-you; he sacrificed his life in the end for the cause. Marcos affectionately refers to him as the Linnaeus or Ameghino of la Joda (Cortázar 1978: 242) because of his obsession with organizational problems.

Gómez, Roland and Lucien Verneuil are portrayed as the radicals of la Joda because of their extremist views. Andrés refers to them by saying: "Gómez and Roland and Lucien Verneuil are of those who will repeat history, you can spot them from far off, they will risk their necks for the revolution, ...but when the afterwards arrives...they'll deny the deepest freedom...I am afraid, I am afraid of the Gómezes and Lucien Verneuils who are the ants of the good side, the fascists of the revolution" (Cortázar 1978: 354).

Gómez and Lucien Verneuil share Rousseau's view that "the state [is] destructive of human freedom and political possibilities" (Delanty 2010: 6) and that the state is the enemy of the people. They could be seen as Marxists as they value the collective interests of the community over the individual. Similarly, they could also be classified as communists, socialists or anarchists. Gómez is against all forms of capitalism even in the aesthetics, as he disapproves of bourgeois music.

\section{Conclusions}

This article focuses on various theoretical concepts of community, and how these relate to the fictional community of $l a$ Joda in Libro de Manuel. La Joda is a diverse community made up of members who all contribute their part in minirevolutions or micro-agitaciones; it is a community based on cooperation, pluralism and moral individualism, to use the terms of Durkheim (1964). La Joda represents for its members a quest for freedom at an individual and a collective level (Valentine 1974). In this community, individuals play special roles: Marcos is the leader, Susana is the translator, Ludmilla is inspirational as she breathes freshness into things, the-one-I-told-you is the chronicler, Lonstein represents linguistic and sexual liberation, Gómez, Verneuil and Roland are diehard members who would lay down their lives for la Joda, Andrés the intellectual and chronicler and others like Gladis, Monique, Oscar, Heredia and Patricio, all risked their lives in revolutionary acts to change the status quo and renounce human right abuses, and even Manuel, who served as the inspiration for Oscar, Marcos, Susana and Patricio. Another noteworthy thing about this community is the sense of belonging, tolerance and trust among its members, meeting the emotional criteria described by Amit (2002) and Nisbet (2004). Cortázar created a fictional intellectual and revolutionary community with some real-world characteristics, that embarks on a quixotic mission to change the world.

\section{References}

Allende, I. (1982). Casa de los Espíritus. Buenos Aires: Sudamericana.

Amit, V. (ed.) (2002). Realizing Community: Concepts, Social Relationships and Sentiments. London: Routledge. 
Blackshaw, T. (2010). Key Concepts in Community Studies. London: Sage.

Cortázar, J. (1973). Libro de Manuel, Buenos Aires; Sudamericana.

Cortázar, J. (1978). A Manual for Manuel, Trad. Gregory Rabassa, New York: Pantheon Books.

Cohen, A. (1985). Symbolic Construction of Community. London: Routledge.

Delanty, G. (2010). Community. 2nd edition. London and New York: Routledge. First published 2003.

Durkheim, E. (1964). The Division of Labour in Society. Glencoe, IL: The Free Press. First published 1893.

Etzioni, A. (1995). The Spirit of Community. London: Fontana Press.

Fernández Utrera, M. S. (1996). "Julio Cortázar y Libro de Manuel: pensamiento y narrativa en torno al concepto de "revolución”. Revista Canadiense de Estudios Hispánicos, 20(2), pp. 225-240

Flores, G. (2011). Comunidad, individuo y libertad.: El debate filosófico-político sobre una triada (pos)moderna. Tramas Vol. 34, 34, pp. 15-46

Francescato, M. P. (1976). The New Man (But Not the New Woman). Books Abroad, Vol. 50, No. 3, pp. 589-595.

Juan-Navarro, S. (1999). Postmodernist Collage and Montage in Julio Cortázar's" Libro de Manuel”. In Critical Essays on Julio Cortázar. Ed. Jaime Alazraki. pp. 173-192. New York: G.K. Hall \& Co.

Kymlicka, W. (1996). Ciudadanía Multicultural. Barcelona: Paidós.

Martín, O. (2009). Libro de Manuel, antes y ahora real: Julio Cortázar. Espéculo: Revista de estudios literarios. http://www.ucm.es/info/especulo/numero43/limanuel.html.

Nisbet, R.A. (2004). The Sociological Tradition. New Brunswick \& London: Transaction Publishers. First published 1966.

Planells, A. (1980). Del "ars masturbandi" a la revolución: Libro de Manuel de Julio Cortázar. Cahiers du monde hispanique et luso-brésilien, No. 35, pp. 43-58.

Putnam, R. D. (2000) Bowling Alone. The collapse and revival of American community. New York: Simon andSchuster.

Smith, M. K. (2001) 'Community' in the Encyclopedia of Informal Education. http://www.infed.org/community/community.htm.

Turner, V. (1969). The Ritual Process: Structure and Anti-Structure. Chicago: Aldine Publishing.

Valentine, R.Y. (1974). The Artist's Quest for Freedom in Libro de Manuel by Julio Cortázar. Chasqui, 3(2), pp. $62-74$.

Walzer, M. (1997). On Tolerance. New Haven: Yale University Press.

Yovanovich, G. (2011). "La mujer y la violencia en Libro de Manuel de Julio Cortázar.” In Identidades americanas: más allá de las fronteras nacionales. Eds. María del Carmen Sillato and Patricia Varas, pp. 205-225, New Orleans: University Press of the South. 